\title{
Soil Morphological and Physicochemical Properties at Reforestation Sites after Enrichment Planting of Shorea macrophylla in Sampadi Forest Reserve, Sarawak, Malaysia
}

\author{
MUGUNTHAN PERUMAL ${ }^{1 *}$, MOHD EFFENDI WASLI ${ }^{1}$, HO SOO YING $^{1}$, \\ JONATHAN LAT $^{2} \&$ HAMSAWI SANI ${ }^{1}$
}

\begin{abstract}
${ }^{I}$ Department of Plant Science and Environmental Ecology, Faculty of Resource Science and Technology, Universiti Malaysia Sarawak, 94300 Kota Samarahan, Sarawak, Malaysia; ${ }^{2}$ Forest Department of Sarawak, Wisma Sumber Alam, Jalan Stadium, Petra Jaya, 93660 Kuching,
\end{abstract} Sarawak, Malaysia

\begin{abstract}
Implementation of effective soil conservation management is required in order to rehabilitate and manage degraded forest land in the tropics. For the humid tropics of Sarawak, Malaysia, extensive information on the soil characteristics for rehabilitation of degraded forest lands is essential to guide future forest management programme. In this study, a preliminary assessment on the current status of the soil morphological and physicochemical properties at one of the reforestation sites in Sarawak which was established after enrichment planting of Shorea macrophylla in comparison to an adjacent secondary forest was conducted. The soil profiles in the study sites were established at the reforestation areas of different age stand (year 1996; SM96, 1997; SM97, 1998; SM98 and 1999; SM99) planted with S. macrophylla located in Sampadi Forest Reserve as well as existing secondary forest adjacent to the reforestation sites (secondary forest, SF). Soil profile description was conducted at each study sites and soil samples were collected from each identified soil horizon for determination of the soil physicochemical properties. The results showed that the soils in the study area consisted of mainly grey-white podzolic soils which derived from combination of sandstone, coarse-grained, humult ultisols and sandy residual parent material. According to the Sarawak Soil Classification, the morphological properties in the studied sites resemble of Bako soil series as a dominant unit in association with Saratok series in which, corresponds to Typic Paleaquults of Soil Taxonomy by USDA-NRCS Classification. The general soil physicochemical properties indicated that the soils at both reforestation sites and secondary forest were strongly acidic in nature with $\mathrm{pH}$ $\left(\mathrm{H}_{2} \mathrm{O}\right)$ of less than $(\mathrm{pH}<5.5)$ with low nutrient status. The acidic nature of the soils might be ascribed to the presence of high exchangeable Al which concomitantly, increased the level of Al saturation of the studied soils. Observation within each soil profiles indicated that soil acidity decreased with depth, resulting in higher $\mathrm{pH}$ $\left(\mathrm{H}_{2} \mathrm{O}\right)$ at deeper horizons for all studied sites. For the soil total carbon and total nitrogen, soils at secondary forest depicted higher values in total carbon and total nitrogen at surface soils as compared to the reforestation sites which indicate large pool of organic matter at surface soil derived from the above vegetation. In terms of the soil physical properties, the soils observed were relatively of sandy texture and did not varied widely among the studied sites. In addition, the soil bulk density at reforestation sites was relatively higher than secondary forest due to higher penetration of roots and accumulation of organic matter contents in secondary forest. Based on the current progress of this study, it is recommended that determination on the soil characteristics should be taken into consideration as an important indicator prior or during the establishment of reforestation area in order to ensure the success of reforestation activity in tropical rainforests.
\end{abstract}

Keywords: Reforestation, Sarawak, Shorea macrophylla, soil physicochemical properties, tropical rainforests

\section{INTRODUCTION}

Tropical rainforests of Malaysia are considered as the richest and one of the most complex ecosystems in the world in terms of structure and species diversity existing among the earth ecosystems (Whitmore, 1998; FAO, 2001). According to Shukla et al. (1990), tropical rainforests have an outstanding prominent role and main influence in ameliorating and maintaining global climate change by reducing the accumulation of greenhouse gases. Although occupying only $7 \%$ of the earth's land surface, over half of the planet's life forms are found in tropical rainforests (Wilson, 1988). Tropical rainforests not only sustain 
biodiversity but provide homes to indigenous peoples, pharmacopeias of natural products, and provide crucial ecosystem services, such as flood amelioration and soil conservation.

Despite the multi-functional roles and richness, tropical rainforests are fragile habitats and are being destroyed rapidly at unprecedented rates approximately 15.4 million hectares each year due to various disturbances (FAO, 2001). Commercial logging activities for timber resources, shifting cultivation, urbanization industry, natural disturbances like landslide and other forms of encroachment are all principal causes of deforestation in tropical regions. Such disturbances have led to damage in soil resources to a degree which delays the establishment of new succession forest after abandonment (Geist \& Lambin, 2002; ITTO, 2002). Sanchez et al. (2003), Juo \& Franzlueebber (2003) stated that most soils in the tropical regions are infertile, and once the natural forest has been cleared, nutrients can be rapidly lost consequently leading to longer forest recovery time. Thus, widespread of deforestation is creating a landscape in which mature tropical forests are island within an area comprising of various type of successional vegetation.

Degradation in tropical rainforests beyond a threshold and rehabilitations of the forests are critical subject for world foresters, pedologists and ecologists. Nonetheless, Montagnini et al. (1997) stated that the conversion of forested areas to non-forest lands such as to agricultural land have resulted in the permanent reduction of indigenous species including timber species such as Dipterocarp spp. from the Dipterocarpaceae family.

Information on the soil characteristics and morphological properties on a given land can be determined by observing the soil profile development at various depths of the soil. Generally, soil morphological properties deals with the form and arrangement of soil features and can be observed at both field survey and laboratory analysis. In the field, in-situ observation, description and interpretation of the soil within various soil horizons can portray various soil attributes such as soil name, structure, parent materials, erosion, ground water, compaction, consistency and drainage of soils. Nonetheless, field observation on the soil morphological properties can sometimes depicted the land use history of the soil observed. Moreover, although performance of tree growth does reflect the soil characteristics, it is still insufficient to describe soil properties in general given that soil development after land use changes may vary widely depending on the soil heterogeneity as well as the existing environment.

Various previous studies have been conducted on natural forests and its dynamics but still less attention has been paid on the secondary forest succession due to its long term run and difficulties to predict its outcome (Wasli et al., 2009; Zaidey et al., 2010). However, most of the previous studies have emphasized on the growth performance of planted species along with the planting technique with less attention on soil morphological and physicochemical properties under reforestation area. According to the study by Arifin et al. (2008) in Peninsular Malaysia, empirical data on soil properties of rehabilitated degraded forest land planted with dipterocarp species and non-dipterocarp species is still limited. The rehabilitation of the degraded forest ecosystems requires well-understanding of the soil conditions (Ohta, 1990; Ohta et al., 2000). Moreover, Ishizuka et al. (2000) reported that information about the soil properties under degraded vegetation is rather limited, although several studies on the soil properties of tropical rainforests in Sarawak, Malaysia, have been conducted (Beckett \& Hopkinson, 1961; Wood \& Beckett, 1961; Ishizuka et al., 1998). Hence, the objective of this study was to assess the current status of the soils morphological and physicochemical properties of the planted forests under reforestation in comparison to an adjacent secondary forest located at Sampadi Forest Reserve, Sarawak, Malaysia

\section{MATERIALS \& METHODS}

\section{Description of Study Sites}

This study was conducted at Japan-Sarawak Friendship Forest reforestation area at Sampadi Forest Reserve (N01'34'13',, E109 53'12') Lundu, Sarawak which is located about $72 \mathrm{~km}$ 
from southwest of Kuching City (Figure 1). Sampadi Forest Reserve covers approximately 5,163 hectares and has a humid tropical climate, associated with peaks of seasonal changes of rainfall and temperature. The topography at the study site was of low undulating with an average elevation of $87 \mathrm{~m}$ above sea level. It has a tropical seasonal climate (no dry season) with all months receiving on average more than $100 \mathrm{~mm}$ with a subtropical wet forest biozone (Vincent \& Davies, 2003). The climate condition in the area was classified into AA'r on the Thornthwaite classification system (Thornthwaite, 1948). The average annual temperature in the area ranges between $22^{\circ} \mathrm{C}$ $\left(72^{\circ} \mathrm{F}\right)$ in the early hours of the morning and rises to around $31^{\circ} \mathrm{C}\left(88^{\circ} \mathrm{F}\right)$ during midafternoon with little monthly variation (Andriesse, 1972; Meteorological Department, 2010). The soils in the study area comprised of mainly Grey-White Podzolic Soil group which is derived from combination of sandstone, coarse-grained, humult ultisols and sandy residual parent material. According to Sarawak Soil Classification, the morphological properties in the study sites resemble Bako soil series as a dominant unit in association with
Saratok series in which, corresponds to Ultisols of Soil Taxonomy by USDA-NRCS Classification (Soil Survey Staff, 2014).

Prior to the plantation establishment, this area has been under different kinds of land use activities which, in one way or another, affected the edaphic condition of the area. Since the year 1996, Forest Department of Sarawak, along with various international agencies had initiated a reforestation programme by planting various types of Dipterocarp seedlings (mainly of Dipterocarpaceae family) such as Engkabang jantong (S. macrophylla), Kapur bukit (Dryobalanops beccarii), Selangan batu (S. falcifera), Meranti sarang punai (S. parvifolia) and Bintangor bukit (Calophyllum alboramulum) in the study area. The reforestation sites were established under the secondary forests where all tree seedlings were planted under line-planting technique with lines cut $5 \mathrm{~m}$ apart and trees planted at $5 \mathrm{~m}$ interval along the lines. Preparation and maintenance of planting lines were conducted by manual slashing of the undergrowth with bush knife along the planting line. Large pioneer species were left uncut when preparing the planting lines.

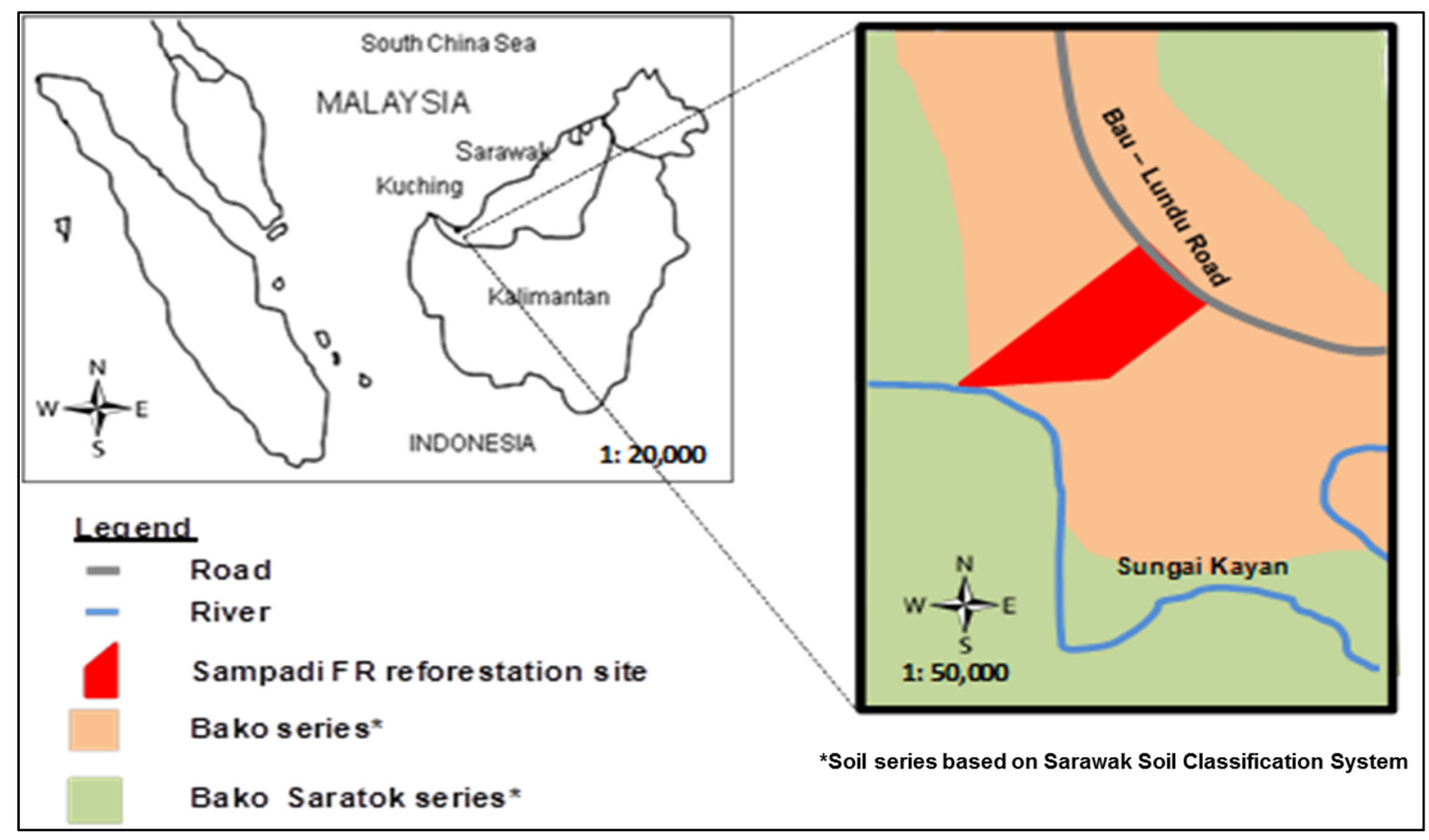

Figure 1. Location of the study area: Sampadi Forest Reserve (Source: Google Map). 


\section{Methods for Soil Profile Description}

Soil profile is the way one typically view soils, although the soil itself should be considered as something that has volume and variability in three dimensions (Schaetzl \& Anderson, 2005). In order to clarify soil morphological and physicochemical properties in a greater detail, a soil pit with the depth of approximately $70 \mathrm{~cm}$ and $1.5 \mathrm{~m}$ width was dug at the center of each study sites. For this purpose, a study plot with the size of $75 \mathrm{~m} \times 50 \mathrm{~m}$ that consisted of 150 planted $S$. macrophylla trees were established within each studied sites. Abbreviation were coded to represent the studied plots; planted with S. macrophylla in the year 1996; SM96, 1997; SM97, 1998; SM98 and 1999; SM99). Soil profile descriptions were conducted adopting the standard procedures by International Soil Science Society (ISSS) (NRCS, 2002). For the typical soil profile (master horizon), the soil profile was described starting from the top of the profile and the characteristics of the soil moving towards the bottom of the profile was observed. Characteristics such as colour, texture, consistence, structure, rock fragments and roots were distinguished. Soil colour was determined by referring to the Munsell Soil Colour chart whereas the texture was determined by "feel method" in the field. Soil hardness (compaction) was measured and examined at every horizon in each study sites by using the Yamanaka-type push cone penetrometer. Soil samples were collected at each horizons depth of the soil profile for soil physicochemical analyses.

\section{Methods for Soil Physicochemical Analyses}

The collected soil samples were air-dried for a week, crushed, homogenized and passed through a $2 \mathrm{~mm}$ mesh-sieve before the soil physicochemical analyses were conducted. All plant materials such as fine roots, twigs and leaves were removed carefully. As for the soil physical analysis, particle size distribution was determined using the pipette method (Gee \& Bauder, 1986). Soil bulk density was determined on the undisturbed samples, collected at each soil horizon depth using a $100 \mathrm{cc}$ core sampler with the ratio of dry mass of soil to the bulk volume of soil core. Soil $\mathrm{pH}$ was measured in distilled water, $\mathrm{H}_{2} \mathrm{O}$ and (soil to solution ratio of 1:5) by the glass electrode method (denoted as $\mathrm{pH}_{\mathrm{w}}$ ). Total Carbon (T-C) content in soil was determined using loss on ignition method (Atkinson et al., 1958, in McKeague, 1976). In addition, the soil Total Nitrogen (T-N) content was determined by Kjeldahl acid digestion and tested with Hach DR/890 Colorimeter. Available Phosphorus content in soil was determined by the Bray II method (Bray \& Kurtz, 1945; Kuo, 1996) with $\mathrm{UV}-\mathrm{V}$ is Spectrophotometer at a wavelength of $710 \mathrm{~nm}$ (Jasco V-630). The contents of soil exchangeable bases $(\mathrm{Ca}, \mathrm{Mg}, \mathrm{K}$ and $\mathrm{Na}$ ) were extracted three times with $1 \mathrm{M}$ ammonium acetate, $\mathrm{NH}_{4}-\mathrm{OAc}$ adjusted to $\mathrm{pH} 7.0$ and $10 \%$ $\mathrm{NaCl}$ and the concentrations of $\mathrm{Ca}, \mathrm{Mg}, \mathrm{K}$ and $\mathrm{Na}$ were determined with the atomic absorption spectrophotometer (AAS) (Thermo Scientific, ICE Series 3500). Titration methods were used to determine cation exchange capacity (CEC) of the soil. The filtrate from the $\mathrm{pH}(\mathrm{KCl})$ measurement was used for soil exchangeable $\mathrm{Al}$ analysis. Exchange acidity $(\mathrm{Al}+\mathrm{H})$ was determined using the titration method with 0.01 $\mathrm{M} \mathrm{NaOH}$ and the content of the exchangeable Al with $0.01 \mathrm{M} \mathrm{HCl}$. All soil physicochemical analyses were conducted at Laboratory of Environmental Soil Science, Faculty of Resource Science and Technology, Universiti Malaysia Sarawak (UNIMAS).

\section{RESULTS AND DISCUSSION}

\section{Soil Morphological Properties under Various Age Stands and Secondary Forest at Sampadi Reforestation Area}

In this study, the summary of all descriptions and interpretations of soil profiles as well as the view of the observed representative soil profiles were shown in Table 1 and Figure 2, respectively. Based on the in-situ observation during field sampling, the area consisted of existing vegetation which derived after the previous land use were dominated by several woody pioneer tree species and brush species such as Benuah (Macaranga spp.), Buan or Simpor (Dillenia suffructicosa) and Kayu Ara (Ficus spp.).

Soil profiles in all study sites showed the existence of sandy, clayey, silty and loamy texture in the horizons. Thus, according to the Sarawak Soil Classification Systems, the 
occurrence of Bako series, which derived from sandy residual parent material as a dominant unit in association with Saratok series that have a coarse loamy or coarse silty particle size were evident in the study area (Andriesse, 1972). Under the Bako series, it is known as Podzols and can be found typically on nearly flat ridges tops or dip slopes such as the topography of lowland and low undulating hill of Sampadi Forest Reserve. Although no mottling was observed in all horizons of all profiles, one of the significant features of Bako series was the appearance of well-cemented spodic horizon which represents a subsurface horizon in which alluvial organic matter precipitated.

Meanwhile, Teng (2004) reported that Saratok series, which is known as GreyWhite Podzolic soils can be found formed in residuum derived mainly from sandstone. This can be detected by the presence of a coarse loamy or coarse silty; or contrasting texture where the upper $50 \mathrm{~cm}$ depth was with coarse loamy and coarse silty texture in the soil profiles. According to the USDA Soil Taxonomy, this Grey-White Podzolic soil group corresponds to Typic Paleaquults (Soil Survey Staff, 2014).

Based on the soil profile description in plot SM98 and SM99, all the soils observed were deep with silty clay loam texture. Meanwhile, the presence of clay was only observed in plot SM97 and SF. It can be assumed that in SM96 soil profile, the silty clay texture may present deeper in the soil horizons than that of SM98 and SM99 soil profiles. Therefore, in terms of parent material, this information can be used to define the study area.

Our results showed that the depth of $\mathrm{O}$ horizon in the reforestation area (SM96, SM97, SM98, SM99) were similar ranging from 1-3 $\mathrm{cm}$ as compared to the secondary forest soils which consisted of $4 \mathrm{~cm}$ thick of $\mathrm{O}$ horizon
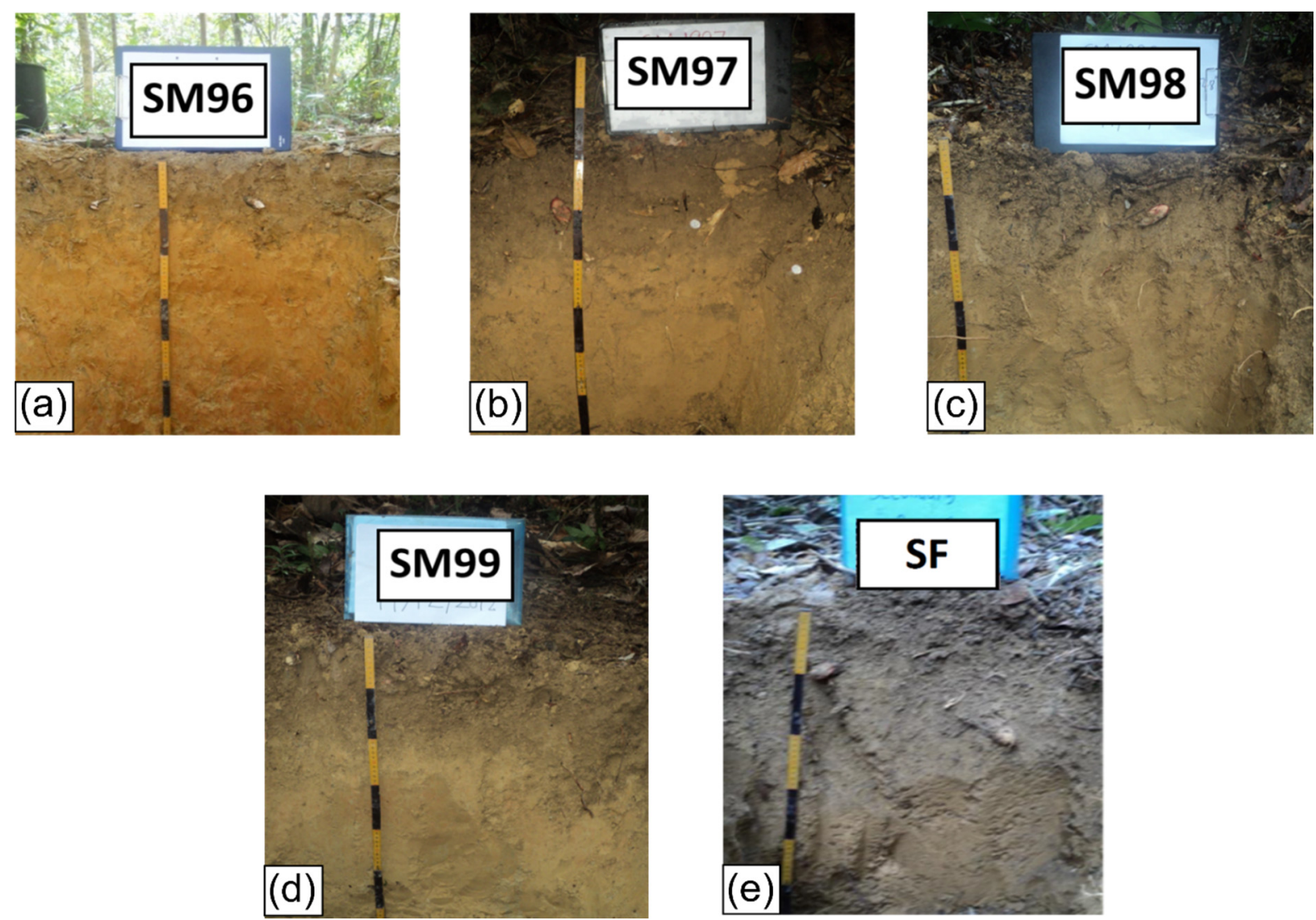

Figure 2. Image of soil pit for profile description in the study sites: (a) Soil profile for SM96 site; (b) Soil profile for SM97 site; (c) Soil profile for SM98 site; (d) Soil profile for SM99 site; (e) Soil profile for SF site. 
Table 1. Summary of morphological properties of the soils in Sampadi Forest Reserve.

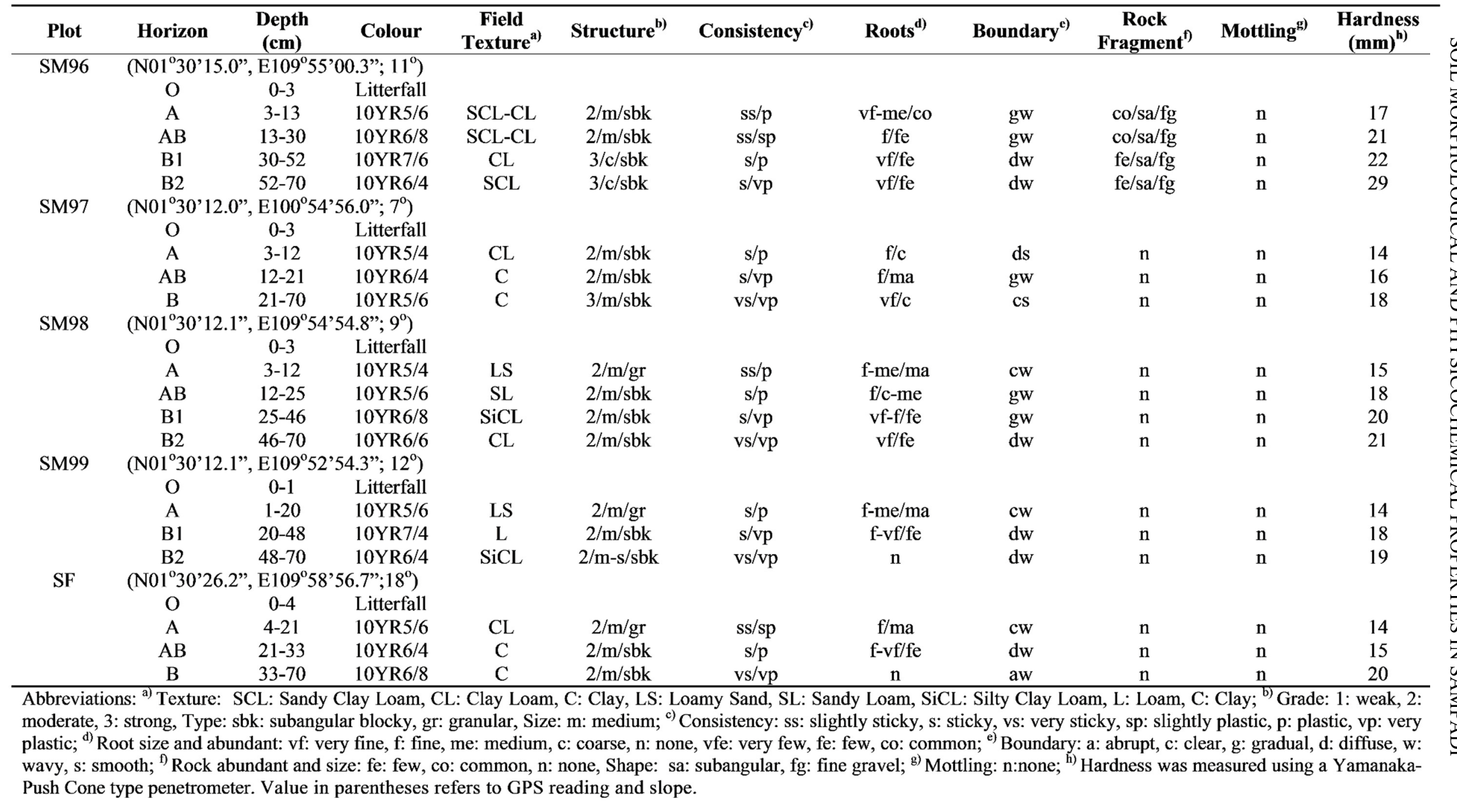


layer. This slight difference between both areas (reforestation area and secondary forest) leads to the possibility that there were other plots in the secondary forest which might have the depth of $\mathrm{O}$ horizon that was more than in the reforestation area. The thin $\mathrm{O}$ layer at the reforestation sites was probably due to the supply of raw materials since the trees were considered as in immature stage (from 15 years-old to 18 years-old) in comparison to a continuous supply of organic matter from mature vegetation in secondary forest. This $\mathrm{O}$ horizon was the layer where litterfall from the $S$. macrophylla and other pioneer tree species accumulate and cover the topsoil. Decomposition occurs reflects the activity of decomposer that soon returns nutrient back to the soil. Level of soil fertility can be indicated as it forms a layer which regulates the access of soil in getting enough requirements as rainfall and sunlight to maintain its form and structure.

Nonetheless, the soil colour at A horizon of reforestation areas (SM96, SM97, SM98 and SM99) did not differ much as the colour of the soil was within the range of $10 \mathrm{YR} 5 / 4$ to 10YR5/6 which were from yellowish brown to brownish yellow. The accumulation level of organic matter from the vegetation as well as density of below ground biomass in artificial forest promote higher activity of soil microorganism, which leads to high decomposition rate of organic material in the $\mathrm{A}$ horizon. In addition, it should be noted that high mineralization of organic matter at subsoil layer could also lead to high accumulation of organic matter or humus. Similar findings on the accumulation of organic matter in the top soil had been reported by Ishizuka et al. (1998, 2000). Moreover, Hattori et al. (2005) found that the accumulation of organic materials were higher in the surface horizon at remnant forest than other degraded land in Sarawak, Malaysia.

On the other hand, relative similarities among other morphological properties at this $\mathrm{A}$ horizon, such as soil consistence, and structure as well as the soil roots were observed in all soil profiles, with the soil texture ranged from sandy clay loam to loamy sand which allow the penetration of roots around $5-10 \%$ and absorption of water to maintain soil moisture. Fine roots were observed in the uppermost layer of the soils across the study areas to the deeper part of the solum, except at the lower part of soil at SM99 and SF sites. This was due to the moderate grade of soil structures and friable consistence, resulting from the sandy clay loam to loamy sand texture in all the sites. Even though differences were observed in term of the soil hardness between all study sites, the soil hardness especially in SM96 depicted the highest in value as compared to other study sites. Based on the preliminary assessment from previous study conducted by Perumal (2012) reported that it was not a limiting factor for the growth of $S$. macrophylla in SM96 since fine roots were able to penetrate the deeper part of the soil which in a way reflects to the assumption that soil compaction might not have occurred in the present study. Thus, the A horizon properties ensures the succession growth of trees as it serves an ideal depth tandem with the ability of roots to penetrate through soil in order to get water and nutrients. Meanwhile, there were no rock fragment and mottling observed at each horizon in all soil profiles except, rock fragment in SM96 site.

\section{Physicochemical Properties of the Soil Profile under Various Age Stands and Secondary Forest in the Study Area}

The physicochemical properties of the soils from soil profiles under various age stands and secondary forest were shown in Table 2.

In general, soil $\mathrm{pH}$ value increases with depth from the surface to $70 \mathrm{~cm}$ for all the soil profiles at the reforestation area and secondary forest as shown in Figure 3. The value of acidity decreased with depth, resulting in the higher $\mathrm{pH}$ $\left(\mathrm{H}_{2} \mathrm{O}\right)$. This suggests that the acidification process tend to be higher in the surface horizon than the subsoil. Kadir et al. (2001) reported that the high acidity in the surface soil was associated with hydrolysis of $\mathrm{Al}$, which was released under strongly leaching conditions and which subsequently lower the soil $\mathrm{pH}$ and caused toxicity. The acidity occurring in the forest soil was due to the presence of $\mathrm{Al}^{3+}$ and $\mathrm{H}^{+}$. According to Zaidey et al. (2010), the increase of $\mathrm{pH}$ with increasing depth maybe related to the contents of $\mathrm{Fe}$ and $\mathrm{Al}$ oxides, while the content of organic matter exhibit high and low pH values. Lines (2004) reported that the rate of decomposition of organic matter depends on the soil's $\mathrm{pH}$. 
Table 2. Physicochemical properties of the soils under various age stands and secondary forest.

\begin{tabular}{|c|c|c|c|c|c|c|c|c|c|c|c|c|c|c|c|c|c|c|c|}
\hline Plot & $\begin{array}{l}\text { Depth } \\
(\mathrm{cm}) \\
\end{array}$ & Horizon & $\mathrm{pH}\left(\mathrm{H}_{2} \mathrm{O}\right)$ & $\begin{array}{c}\mathrm{EC} \\
(\mu \mathrm{s} / \mathrm{cm}) \\
\end{array}$ & $\begin{array}{l}\text { T-C } \\
--(\mathrm{g} \mathrm{k} \\
\end{array}$ & $\begin{array}{l}\mathrm{T}-\mathrm{N} \\
\left.\mathrm{xg}^{-1}\right)--\end{array}$ & CEC & $\mathrm{Ca}$ & Mg & $\begin{array}{l}\mathrm{K} \\
(\mathrm{cmo} \\
\end{array}$ & $\begin{array}{l}\text { Sum of } \\
\text { Bases } \\
\left.\mathrm{dkg}^{-1}\right) \text {--- }\end{array}$ & $\mathrm{Al}$ & ECEC $^{(1)}$ & $\begin{array}{l}\text { Base Sat. }{ }^{(2)} \\
-----(\%)\end{array}$ & Al Sat. ${ }^{(3)}$ & $\begin{array}{c}\text { Av. P } \\
-\left(\mathrm{mg} \mathrm{kg}^{-1}\right) \\
\end{array}$ & $\begin{array}{l}\text { Clay } \\
----(9 \\
\end{array}$ & $\begin{array}{l}\text { Sand } \\
\%) \text {-----( }\end{array}$ & $\begin{array}{c}\mathrm{BD} \\
\left.\mathrm{g} \mathrm{mL}^{-1}\right) \\
\end{array}$ \\
\hline \multirow[t]{3}{*}{ SM96 } & $3--13$ & A & 5.10 & 33.7 & 46.1 & 2.92 & 8.4 & 0.64 & 0.27 & 0.26 & 1.69 & 1.10 & 2.79 & 20.1 & 39.5 & 5.4 & 39.6 & 38.9 & 1.00 \\
\hline & $30--52$ & B1 & 5.43 & 7.5 & 18.4 & 0.84 & 4.8 & 0.02 & 0.02 & 0.14 & 0.65 & 1.10 & 1.75 & 13.6 & 62.7 & 0.7 & 34.4 & 54.5 & 1.51 \\
\hline & $52--70$ & B2 & 5.66 & 6.0 & 11.0 & 0.56 & 3.6 & 0.02 & 0.02 & 0.03 & 0.57 & 0.65 & 1.22 & 15.9 & 53.2 & 0.0 & 27.9 & 61.7 & 1.64 \\
\hline \multirow[t]{2}{*}{ SM97 } & $3--12$ & A & 4.27 & 59.0 & 41.1 & 2.48 & 13.3 & 0.62 & 0.25 & 0.11 & 1.18 & 1.18 & 2.35 & 8.9 & 50.0 & 5.9 & 33.5 & 43.7 & 0.99 \\
\hline & $21--70$ & B & 4.77 & 73.0 & 20.5 & 1.13 & 15.8 & 0.09 & 0.04 & 0.04 & 0.37 & 1.05 & 1.42 & 2.4 & 73.8 & 0.4 & 38.9 & 53.6 & 1.29 \\
\hline \multirow[t]{4}{*}{ SM98 } & $3--12$ & A & 4.52 & 82.0 & 42.7 & 2.33 & 12.8 & 0.56 & 0.25 & 0.09 & 1.25 & 1.30 & 2.55 & 9.8 & 51.1 & 5.7 & 35.5 & 38.6 & 1.13 \\
\hline & $12--25$ & $\mathrm{AB}$ & 4.69 & 76.0 & 30.8 & 2.03 & 13.5 & 0.44 & 0.17 & 0.07 & 1.02 & 1.35 & 2.37 & 7.5 & 57.1 & 1.6 & 35.8 & 18.0 & 1.20 \\
\hline & $25--46$ & B1 & 4.88 & 69.0 & 24.7 & 1.10 & 9.3 & 0.29 & 0.10 & 0.05 & 0.72 & 1.40 & 2.12 & 7.8 & 66.0 & 1.1 & 34.9 & 38.4 & 1.37 \\
\hline & $46--70$ & B2 & 5.09 & 63.0 & 21.3 & 0.78 & 13.0 & 0.24 & 0.08 & 0.04 & 0.69 & 1.23 & 1.91 & 5.3 & 64.1 & 0.0 & 39.1 & 46.0 & 1.47 \\
\hline SM99 & $1--20$ & A & 4.75 & 75.0 & 40.1 & 2.38 & 11.0 & 0.40 & 0.24 & 0.10 & 1.07 & 1.18 & 2.25 & 9.8 & 52.2 & 3.7 & 38.0 & 49.2 & 0.97 \\
\hline \multirow{2}{*}{ SF } & $21--33$ & $\mathrm{AB}$ & 5.26 & 15.8 & 30.5 & 1.91 & 9.4 & 0.17 & 0.21 & 0.25 & 1.13 & 1.83 & 2.95 & 12.0 & 61.8 & 1.0 & 49.2 & 30.9 & 0.97 \\
\hline & $33--70$ & B & 5.31 & 12.0 & 30.6 & 1.46 & 10.0 & 0.04 & 0.08 & 0.16 & 0.79 & 1.93 & 2.72 & 7.9 & 70.8 & 0.8 & 57.2 & 33.4 & 1.06 \\
\hline
\end{tabular}



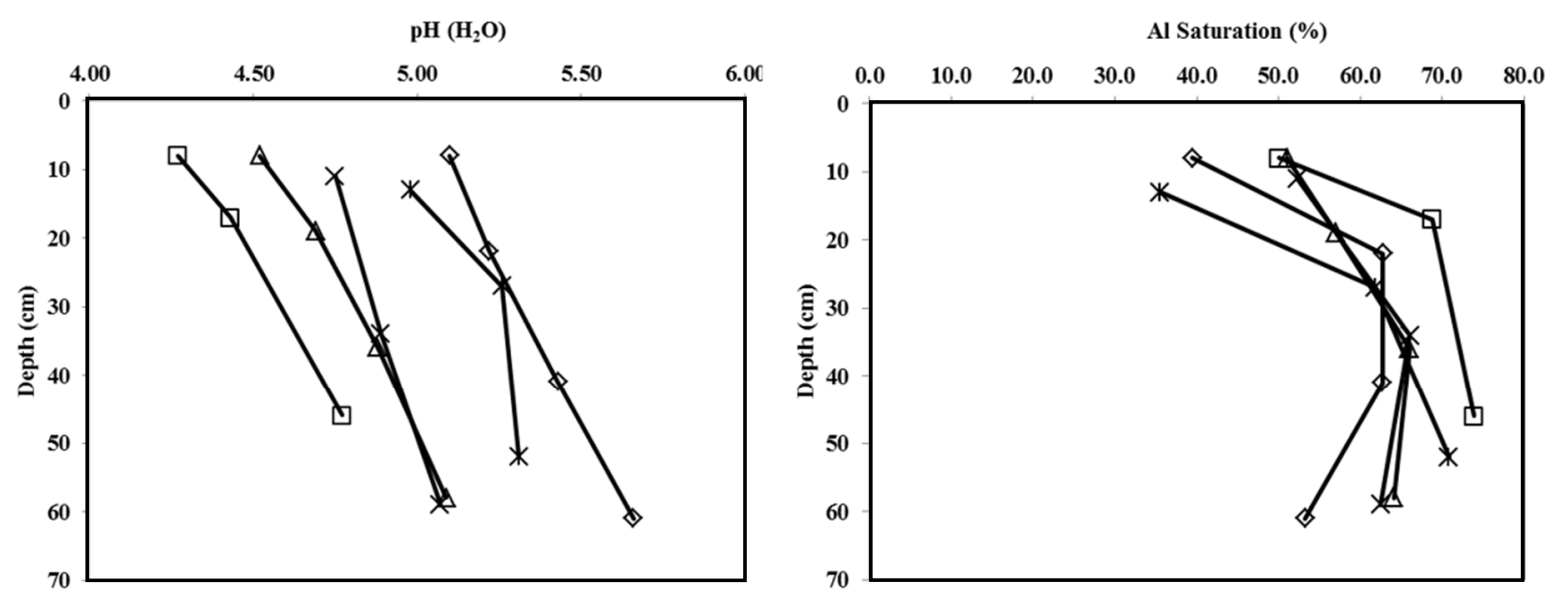

$\multimap$ SM96 —-SM97 $\leftarrow$ SM98 $\leftarrow$ SM99 $\rightarrow$ SF

Figure 3. $\mathrm{pH}\left(\mathrm{H}_{2} \mathrm{O}\right)$ and $\mathrm{Al}$ saturation (\%) at different depths in the study sites.

Generally, soils with high $\mathrm{pH}$ usually contain lesser quantities of organic matter because the soil microorganisms become more active as soil acidity decreases down the soil profiles. On the other hand, the value of Al saturation (percentage of exchangeable $\mathrm{Al}$ content in ECEC) of the soils in reforestation and secondary forest soil profiles was more than $35 \%$ throughout the profiles. It should be noted that high value of $\mathrm{Al}$ saturation is associated with acidic soils.

The values of soil Total Carbon (T-C) and Total Nitrogen (T-N) of the studied sites were shown in Figure 4. The T-C content was higher at surface soil horizons as compared to subsurface soil and tends to decrease with depth in all the sites. According to Ohta and Effendi (1992), the decrease of T-C content with increasing depth also correlated with the clay content in each horizon group and the decomposition rate of soil organic matter. In this study, T-C content in A horizon from secondary forest soil profile depicted the highest value with $47.5 \mathrm{~g} / \mathrm{kg}$ as compared to other sites. The thickness of A horizon was highest in secondary forest among all studied sites. In addition, T-C content from A horizon in SM96 recorded with $46.1 \mathrm{~g} / \mathrm{kg}$, SM97 with $41.1 \mathrm{~g} / \mathrm{kg}$, SM98 with $42.7 \mathrm{~g} / \mathrm{kg}$ and SM99 with
$40.1 \mathrm{~g} / \mathrm{kg}$. The soil T-C content in SM96 was slightly at the range of secondary forest due to the recovering pool of soil carbon in order to reach the value of typical secondary forest. Based on the in-situ observation during field survey, it was suggested that the visibility of charcoal and unburned materials at subsoil layer of SM96 soil profile showed that the site was burnt previously.

Fire intensity during previous burning which derived from clearing of large trees were significant even at subsoil which had resulted in complete decomposition of ground biomass in SM96 site that increased the soil T-C content as well. Nonetheless, higher litterfall rate followed by lower decomposition rate usually results in high litter accumulation and high organic matter. Therefore, it can be assumed that in SM97, SM98 and SM99 sites, they produce high rates of litterfall and decomposition with lowest value of organic matter content as compared to secondary forest and SM96. As for the soil Total Nitrogen (T- N), the results showed a decreased in soil T-N with increasing soil depth. Secondary forest soil profile depicted the highest value in nitrogen content in A horizon with $2.99 \mathrm{~g} / \mathrm{kg}$ followed by SM96 with, $2.92 \mathrm{~g} / \mathrm{kg}$, SM97 with $2.48 \mathrm{~g} / \mathrm{kg}$, SM99 with $2.38 \mathrm{~g} / \mathrm{kg}$ and SM98 with $2.33 \mathrm{~g} / \mathrm{kg}$. . 

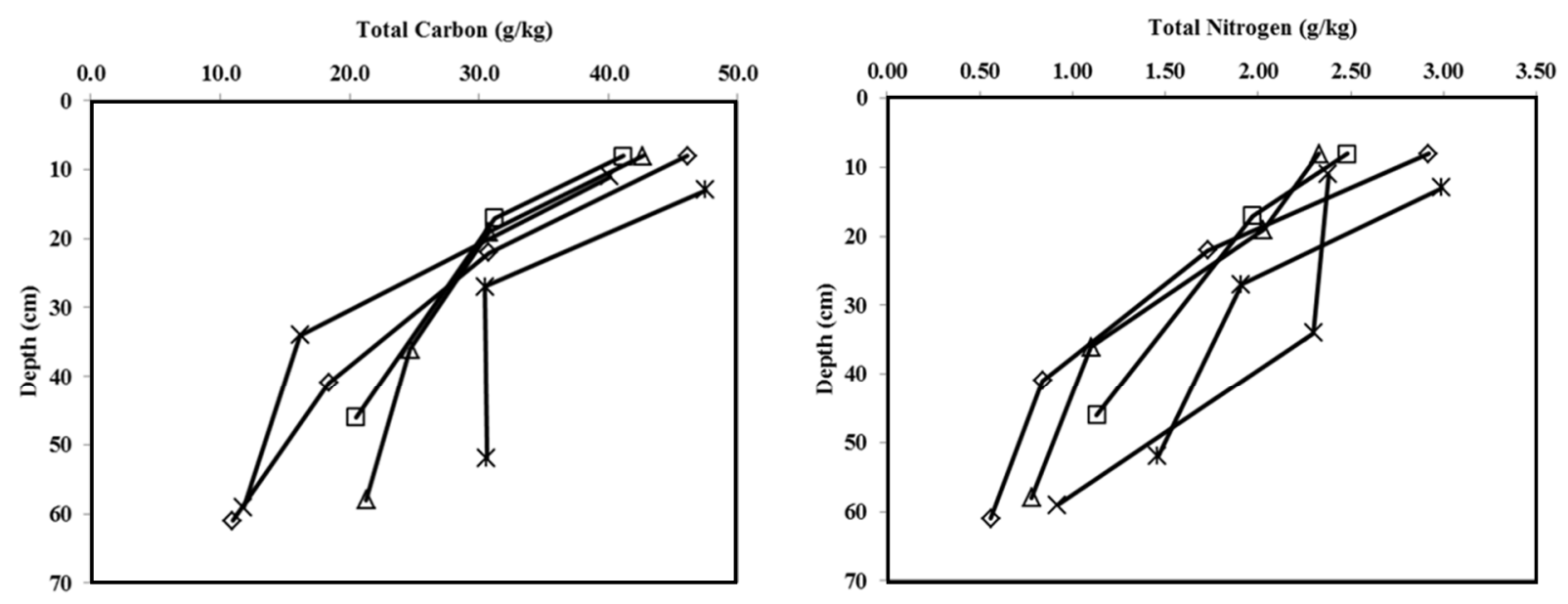

Figure 4. Total carbon $(\mathrm{g} / \mathrm{kg})$ and Total nitrogen $(\mathrm{g} / \mathrm{kg})$ at different depths in the study sites.

However, no clear differences were observed in terms of the soil T-N. The soil T-N content were slightly higher and similar in the uppermost layer of all the studies sites because of the capability of forest soils in reforestation sites and secondary forest to accumulate large amount of organic matter, mainly supplied by the above mature vegetation (Zaidey et al., 2010).

The values of soil Effective Cation Exchange Capacity (ECEC) and soil exchangeable bases for $\mathrm{Mg}, \mathrm{Ca}$ and $\mathrm{K}$ were shown in Figure 5. In general, the soil ECEC decreases with increasing depth down the soil profile in all the study sites. Secondary forest sites recorded the highest value in ECEC as compared to the reforestation sites (SM96, SM97, SM98 and SM99). Several researchers found out that the negative charge derived from the clay minerals may have affected the CEC of the soil (Ohta et al., 1993; Sakurai et al., 1998; Tanaka et al., 2007; Arifin et al., 2008). Based on Figure 5, the soil exchangeable bases decreased with increasing depth. The content of exchangeable bases was higher in the surface soils than those of the subsurface soils.

According to Soto and Diazfierroz (1993), the higher contents of $\mathrm{Ca}$ and $\mathrm{Mg}$ in the surface soil were due to the association of biological accumulation from plant. In addition, the exchangeable $\mathrm{K}$ from decomposition of dead plants might be dissolved easily into the deep layer of soil because of heavy rainfall. High amounts of exchangeable $\mathrm{Ca}$ and $\mathrm{Mg}$ in the soils at the planting site were also assumed to result from the clear-felling and burning prior to the establishment of the rehabilitation project. Hattori et al. (2005) reported that a large amount of these cations were present in the surface layer of soils in the grassland after burning. On the other hand, Ohta \& Effendi (1992) mentioned that subsoil may also play an important role as a nutrient storage whereby some parts of the nutrients in the subsoil are pumped up slowly to the topsoil resulting in the accumulation of cations in the subsurface soil.

Figure 6 shows the distribution of soil bulk density and soil hardness of the studied sites. The soil bulk density value increases with increasing depth throughout all the soil profiles. The reforestation plots (SM96, SM97, SM98 and SM99) had higher bulk density as compared to the secondary forest profiles. The secondary forest had a low bulk density due to higher penetration of roots, accumulation of organic matter and soil life. Root elongation increases the porosity of soil. Tan (2005) 

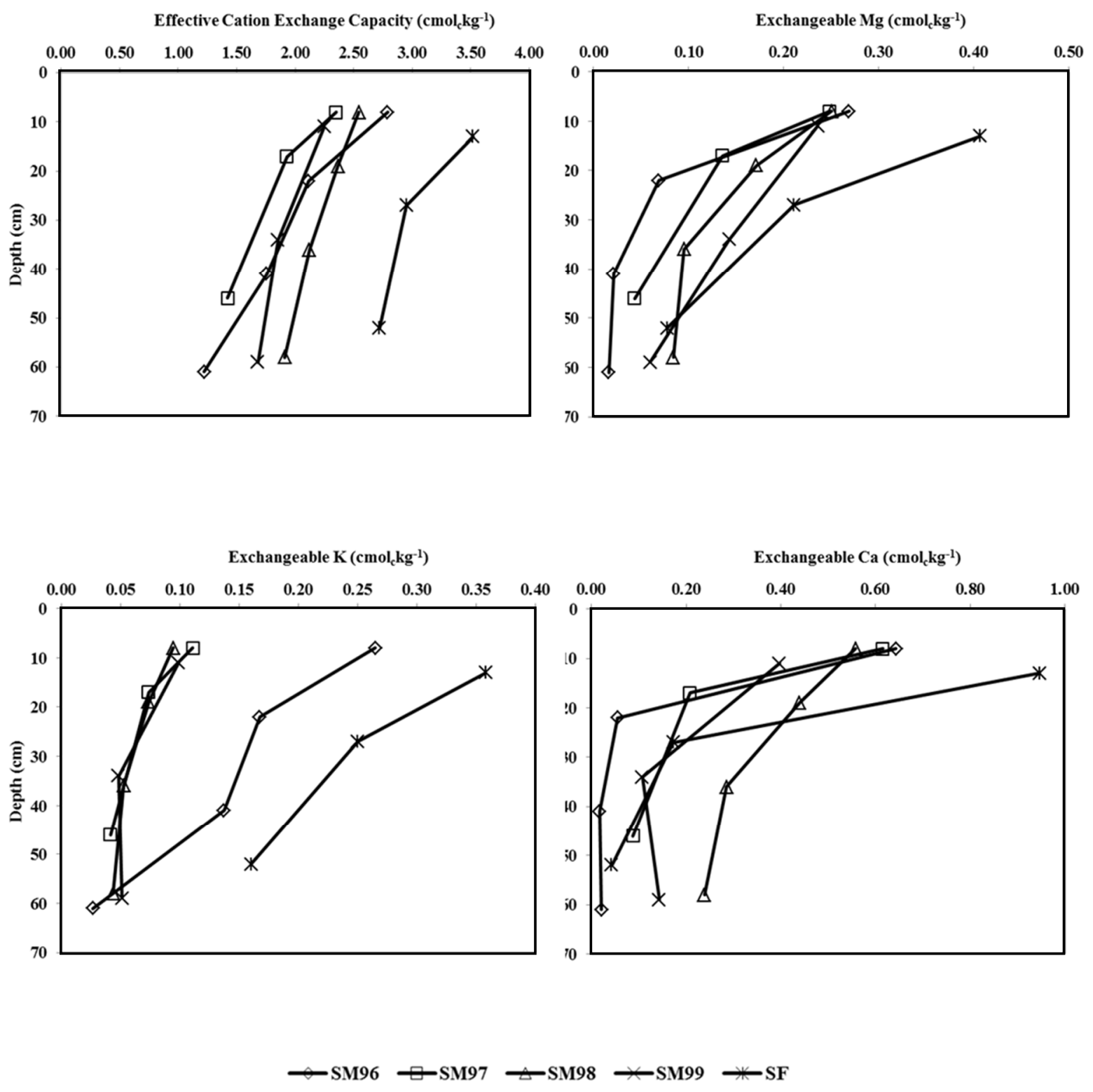

Figure 5. Effective cation exchange capacity $\left(\mathrm{cmol}_{\mathrm{c}} \mathrm{kg}^{-1}\right)$ and exchangeable bases $(\mathrm{Mg}, \mathrm{Ca}$ and $\mathrm{K}), \mathrm{cmol}_{\mathrm{c}} \mathrm{kg}^{-1}$ at different depths in the study sites.

reported that the pore in the soils develops due to the penetrations of roots, worms and other forms of soil life. Bulk density is also influenced by the content of organic matter. According to Alexander (1989), higher organic matter content consequently decreased the value of the bulk density of soils. This is consistent with secondary forest soil profile since it had the highest content of organic matter.

In addition, there was a slight variation in terms of soil hardness or compactness increasing the depth down the soil profile in all study sites. The soil hardness increased with increasing depth of the soil horizons. SM96 soil 

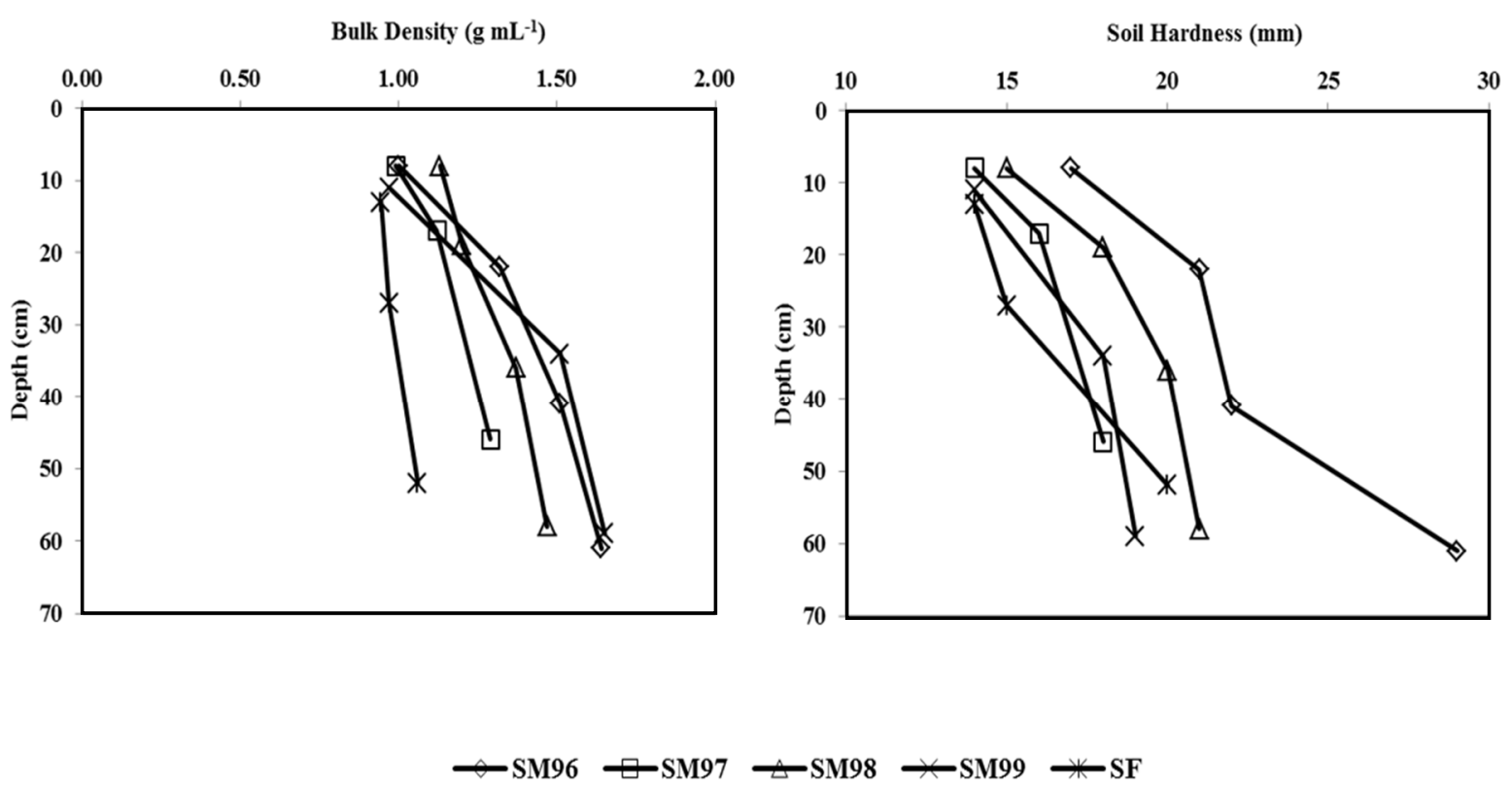

Figure 6. Bulk density $\left(\mathrm{g} \mathrm{mL}^{-1}\right)$ and soil hardness $(\mathrm{mm})$ at different depths in the study sites.

profile depicted the highest value in soil hardness followed by SM98 soil profile, SM97 soil profile, SM99 soil profile and secondary forest soil profile. Although this reflects that soil compaction did not occur and was not a limiting factor to the tree growth of $S$. macrophylla, the A horizon properties ensures the succession growth of trees in SM96. The soil hardness was significantly high probably because of the dead and carbonized tree roots of the former vegetation (Ogino et al., 2000). Meanwhile, the surface soils in the secondary forest showed a lower value of hardness than in other reforestation sites, presumably due to the presence of a relatively thick $\mathrm{O}$ horizon in the secondary forest (Hattori et al., 2005).

Based on the current status of soil physicochemical properties obtained, the soils at reforestation sites and secondary forest were formed from similar parent materials and consisted of different types of vegetation cover. It can be deduced that the soils at the reforestation sites especially SM96 were slightly at the range of secondary forest due to the recovering pool of soil in order to reach the value of typical secondary forest.

\section{CONCLUSION}

Information on current status of the soil properties under rehabilitated forest of various age stands is vital in order to know the suitability of the site which has been planted with $S$. macrophylla for reforestation activities in comparison to an adjacent secondary forest. Our findings indicated that the soils in the study area consisted of sand, silt, clay and loam texture in the horizons of the soil profiles. In addition, the soils in the study area comprised of mainly Grey-White Podzolic soils which derived from combination of sandstone, coarsegrained, humult ultisols and sandy residual parent material. Nevertheless, such soil indicates the existence of Bako soil series as a dominant unit in association with Saratok series, in which corresponds to Typic Paleaquults of Soil Taxonomy by USDANRCS Classification.

The accumulation layer of clay mostly in B horizon does not serve a good medium for roots to anchor the soil structure in order to maintain the body of tree to thrive well under extreme condition such as strong winds and heavy 
flood. The presence of clay contributes to low water retention which may related to the occurrence of heavy flood that happened almost every year in this area. In fact, this type of soil is also consider as very marginal for tree plantation establishment because of their low fertility, low nutrient, low water retention capacity and shallow rooting depth. In terms of soil physicochemical properties, generally the soils at the reforestation sites especially in SM96 was slightly at the range of secondary forest due to the recovering pool of soil in order to reach the value of typical secondary forest.

This study can be further continued with other plots in the reforestation area in order to get more information on soil morphological and physicochemical properties for the recovery ofthe degraded soil ecosystem. Further research will be more valuable to find out if there is any other tree species can survive under the same type of soil such as $S$. macrophylla.

\section{ACKNOWLEDGEMENTS}

We wish to express our gratitude to the Director and staff of the Forest Department, Sarawak for their supportive assistance and companionship during the duration of this study. This research was financially supported by the research grant from Fundamental Research Grant Scheme (FRGS (E14099/F07/69/989/2013(30)) and Dana Pembudayaan Penyelidikan (RAGS (RAGS/g(2)/914/2012(15)) from Ministry of Higher Education, Malaysia, Grant-in-Aid for scientific research purpose by the JapanMalaysia Association (JMA) and NPO Rainforest Sarawak.

\section{REFERENCES}

Alexander, E.B. (1989). Bulk density equations for Southern Alaska soils. Canadian Journal of Soil Science, 69: 177-180.

Andriesse, J.P. (1972). The soils of West Sarawak (East Malaysia). Memoir 1. Soils Division, Department of Agriculture, Sarawak.
Arifin, A., Tanaka, S., Jusop, S., Majid, N.M., Ibrahim, Z., \& Sakurai, K. (2008). Rehabilitation of degraded tropical rainforest in Peninsular Malaysia with a multi-storied plantation technique of indigenous dipterocarp species. Journal of Forest Environment, 50: 141-152.

Atkinson, H.J., Giles, G.R., MacLean, A.J., \& Wright, J.R. (1958). Chemical methods of soil analysis. Contrib. No 169 (revised), Chem. Div., Sci. Serv., Canada Department of Agriculture, and Ottawa, ON. In: Mckeague, J.A. (Ed.), 1976. Manual of soil sampling and methods of analysis. Soil Research Institute, Agriculture Canada, Ottwa, ON.

Beckett, P.H.T. \& Hopkinson, D. (1961). Some sarawak soils. i soils of the region centered on the Usun Apau plateaux. Journal of Soil Science, 12: 41-51.

Bray, R.H. \& Kurtz, L.T. (1945). Determination of total, organic and available forms of phosphorus. Soil science, 59(1): 39-46.

Food and Agriculture Organization of the United Nations (FAO) (2001). Global forest resources assessment 2000. Food Agriculture Organization, Rome, Italy.

Gee, G.E. \& Bauder, J.W. (1986). Particle-size Analysis. In: Klute, A., Campbell, G.S., Jackson, R.D., Mortland, M.M. and Nielsen, D.R. (Eds.). Method of soil analysis. Part 1. Physical and mineralogical methods., Soil Sci. Soc. of America, Inc. and America Soc. Agronomy, Inc., Madison, Wisconsin. Pp 399-404.

Geist, H.J. \& Lambin, E.F. (2002). Proximate causes and underlying driving forces of tropical deforestation. Bioscience, 52: 143150.

Hattori, D., Sabang, J., Tanaka, S., Kendawang, J.J., Ninomiya, I., \& Sakurai, K. (2005). Soil characteristics under three vegetation types associated with shifting cultivation in a mixed dipterocarp forest in Sarawak, 
Malaysia. Soil Science and Plant Nutrition, 51: 231-241.

ITTO. (2002). Guidelines for the restoration, management and rehabilitation of degraded and secondary tropical forests. ITTO. Policy Development Series 13, Yokohama, Japan.

Ishizuka, S., Tanaka, S., Sakurai, K., Hirai, H., Hirotani, H., Ogino, K., Lee, H.S., \& Kendawang, J.J. (1998). Characterization and distribution of soils at Lambir Hills National Park in Sarawak, Malaysia, with special reference to soil hardness and soil texture. Tropics, 8: 31-44.

Ishizuka, S., Sakurai, K., Kendawang, J.J., \& Lee, H.S. (2000). Soil characteristics of an abandoned shifting cultivation land in Sarawak, Malaysia. Tropics, 10: 251-263.

Juo, A.S.R. \& Franzluebbers, K. (2003). Tropical soils: properties and management for sustainable agriculture. Oxford: Oxford University Press. Pp 281.

Kadir, S., Ishizuka, I., Sakurai, K., Tanaka, S., Kubota, S., Hirota, M., \& Priatna, S.J. (2001). Characterization of ultisols under different wildfire in South Sumatra, Indonesia, I. Physico-chemical properties. Tropics, 10: 565-580.

Kuo, S. (1996). Phosphorus. In: Sparks, D.L., Page, P.N., Tabatabai, M.A., Johnston, C.T., \& Summer, M.E. (Eds.). Method of soil analysis. Part 3-chemical methods. Soil Sci. Soc. America, Inc. and American Soc. Agronomy, Inc., Wisconsin. Pp 869919.

Lines, R. (2004). Soil Organic Matter: Decomposition. http://www.dpi.nsw.gov. au/agriculture/resources/soils/structure/org anic-matter. Downloaded on 28.8.2015.
Meteorological Department. (2010). Weather data (air temperature) 2001-2010. Meteorological Department, Sarawak, Kuching.

Montagnini, F., Eibl, B.M., Grance, L., Maiocco, D., \& Nozzi, D. (1997). Enrichment planting in overexploited subtropical forests of the Paranaense region of Misiones, Argentina. Forest Ecology Management, 99: 237-246.

Natural Resources Conservation Services, United States Department of Agriculture, (NRCS). (2002). In: Schoeneberger, P.J., Wysocki, D.A., Benham, E.C., \& Broderson, W.D. (Eds). Field book for describing and sampling soils, version 2.0. Lincoln, NE: Natural Resources Conservation Service, National Soil Survey Center.

Ogino, K., Lee, H.S., \& Kendawang, J.J. (2000). Proceeding of workshop on forest ecosystem rehabilitation. Sarawak: Forest Department Sarawak.

Ohta, S. (1990). Influence of Deforestation on the Soils of the Pantabangan Area, CentralLuzon, the Philippines. Soil Science and Plant Nutrition, 36: 561-573.

Ohta, S. \& Effendi, S. (1992). Ultisols of lowland dipterocarp forest in east Kalimantan, Indonesia. II. Status of carbon, nitrogen and phosphorus. Soil Science and Plant Nutrition, 38: 207-216.

Ohta, S., Effendi, S., Tanaka, N., \& Miura, S. (1993). Ultisols of lowland dipterocarp forest in east Kalimantan, Indonesia: III. Clay minerals, free oxides and exchangeable cations. Soil Science and Plant Nutrition, 39: 1-12. 
Ohta, S., Morisada, K., Tanaka, N., Kiyono, Y., \& Effendi, S. (2000). Are soils in degraded dipterocarp forest ecosystems deteriorated? A comparison of imperata grasslands, degraded secondary forests, and primary forests. In: Guhardja, E., Fatawi, M., Sutisna, M., Mori, T. and Ohta, S. (Eds.). Rainforest ecosystems of east Kalimantan: el-nino, drought, fire and human impacts. Springer-Verlag, Tokyo. Pp 49-58.

Perumal, M., Wasli, M.E., Sani, H., Said, A., \& Nahrawi, H. (2012). Growth performance and survival rate of planted Shorea macrophylla at various age stands in Sampadi Forest Reserve. In: Wasli, M.E., Sani, H., Fasihuddin, B.A., Mohamad, S., Lim, P.T., Lee, K.S. and Sidi, M. (Eds.). Natural resources in the tropics: sustaining tropical natural resources through innovations, technologies and practice. Universiti Malaysia Sarawak. Pp 380-387.

Sakurai, K., Tanaka, S., Ishizuka, S., \& Kanzaki, M. (1998). Differences in soil properties of dry evergreen and dry deciduous forests in the Sakaerat Environmental Research Station. Tropics, 8: $61-80$.

Sanchez, P.A., Palm, C.A., \& Buol, S.W. (2003). Fertility capability soil classification: a tool to help assess soil quality in the tropics. Geoderma, 114: 157185.

Schaetzl, R. \& Anderson, S. (2005). Soils: genesis and geomorphology. United Kingdom: Cambridge University Press.

Shukla, J., Nobre, C., \& Sellers, P. (1990). Amazon deforestation and climate change. Science, 247: 1322-1325.

Soil Survey Staff. (2014). Keys to Soil Taxonomy. (12 ${ }^{\text {th }}$ ed.). US. Department of Agriculture and Natural Resources Conservation Services, Washington, D.C.
Soto, B. \& Diazfierroz, F. (1993). Interaction between plant ash leachates and soil. International Journal of Wildland Fire, 3: 207-216.

Tan, S.S., Primack, R.B., Chai, E.O.K., \& Lee, H.S. (1987). The silviculture of dipterocarp trees in Sarawak, Malaysia Plantation forest. Malaysian Forester, 50: 148-161.

Tanaka, S., Wasli, M., Kotegawa, T., Seman, L., Sabang, J., Kendawang, J.J., Sakurai, K., \& Morooka, Y. (2007). Soil properties of secondary forests under shifting cultivation by the Iban of Sarawak, Malaysia in relation to vegetation condition. Tropics, 16: 385398.

Teng, S.C. (2004). Keys to soil classification of Sarawak. Agriculture Department of Sarawak. Pp 68.

Thornthwaite, C.W. (1948). An approach toward a rational classification of climate. Geographical Review, 38: 55-94.

Vincent, A. \& Davies, S.J. (2003). Effects of nutrient addition, mulching and plantinghole on early performance of Dryobalanops aromatica and Shorea parvifolia planted in secondary forest in Sarawak, Malaysia. Journal of Forest Ecology and Management, 180: 261-271.

Wasli, M.E., Tanaka, S., Kendawang, J.J., Seman, L., Unang, B., Lat, J., Abdu, A., Morooka, Y., \& Sakurai, K. (2009). Vegetation conditions and soil fertility of fallow lands under intensified shifting cultivation systems in Sarawak, Malaysia. Tropics, 18: 115-126.

Whitmore, T.C. (1998). An introduction to tropical rain forests. ( $2^{\text {nd }}$ ed.). Oxford: Oxford University Press. Pp 282.

Wilson, E.O. (Ed.). (1988). Biodiversity. National Academy of Sciences, Washington, D.C. 
Wood, T.W.W. \& Beckett, P.H.T. (1961). Some Sarawak soils. II Soils of the Bintulu coastal area. Journal of Soil Science, 12: 218-233.
Zaidey, A.K., Arifin, A., Zahari, I., Hazandy, A.H., Zaki, M.H. Hassan, A., Wasli, M.E., Hafiz, Y.K., Shamshuddin, J., \& Muhamad, M.N. (2010). Characterizing soil properties of lowland and hill dipeterocarp forests at Peninsular Malaysia. International Journal of Soil Science, 5(3): 112-130. 